International Journal of Linguistics, Literature and Translation

ISSN: 2617-0299 (Online); ISSN: 2708-0099 (Print)

DOI: 10.32996/ijltt

Journal Homepage: www.al-kindipublisher.com/index.php/ijllt

\title{
An Analysis of Santiago's Character in Hemingway's The Old Man and the Sea : A Saga of Indomitable Human Spirit
}

\author{
Dr. Rummana Farooqui 8 (D) \\ Assistant Professor, Department of English Language and Literature, University of Bahrain, Bahrain \\ Corresponding Author: Dr. Rummana Farooqui, E-mail: rummana.farooqui53@gmail.com
}

\author{
ARTICLE INFORMATION \\ Received: April 14, 2021 \\ Accepted: May 22, 2021 \\ Volume: 4 \\ Issue: 5 \\ DOI: 10.32996/ijllt.2021.4.5.20
}

\section{KEYWORDS}

Dignity, struggle, survival, resolution, bravery, perseverance, indomitable, hope, despair

\section{ABSTRACT}

This article explores the epic story of an old fisherman and his experience at the sea that portrays the physical and emotional strength of a man called Santiago and will analyse his motivation to reclaim his lost reputation and dignity of not catching a fish for 84 days. Santiago confronted each day with poise and dignity for many days without catching a fish and was made fun of by many fishermen. He was called unlucky (salao) by the fellow fishermen. Hemingway illustrates the daring resolution of the old man through this tale. The story deals with the vital issues of mortality, hope, despair, and determination, where an old fisherman fights back against a huge fish to reclaim his honour and dignity. Ernest Hemingway rejoices over this heroic man who goes through life's challenges alone with fierce courage and tenacity, exhibiting what Hemingway views as an indestructible spirit of man at its best. In addition, Hemingway reminds us about the human spirit and the importance of human dignity in our everyday struggle for survival. Hemingway compels us to acknowledge courage, tenacity, skill, expertise, and strength through this story. He recalls a tale of valour, daring, and heroism, of one man's struggle against his own doubts and about his success and failure, and his ultimate triumph. The novel brings forth man's understanding of his own mortality and his power to overcome it. The objective of this study is to analyse the character of Santiago, based on the structural elements, using qualitative research.The primary data of the research is The Old Man and the Sea and the secondary data of the research are the other materials related to the study. The result of the study shows following conclusion.Based on the research the character of Santiago's struggle displays the aptitude of the indomitable spirit of man that endures suffering and adversity in order to succeed. The story illustrates Santiago's adventure and resolution, hardship and perseverance.

\section{Introduction}

The objective of this research is to examine the psychological and moral aspects of Santiago's character based on the novel and its subsequent influence on his motivation to maintain his dignity and explores the emotions of hope and despair and its impact on Santiago in the novel, The Old Man and the Sea. The story also deals with the eternal attributes of survival, love, appreciation, dignity, tenacity, and success against all odds.

The Old Man and the Sea was the last major work of fiction written by Hemingway that was published during his lifetime. It tells the story of an old fisherman, Santiago, who struggles with a huge marlin far out in the Gulf Stream off the coast of Cuba. Throughout his struggle on the sea to catch the fish, he uses all his strength and courage to firmly hold on to the fishing line with wounded hands. As Topham (2019), states, the old fisherman clasps onto the fishing line as though his life relies on it. In this part of the story, it seems the author wants to bring forth the supremacy and masculinity of an ordinary man and shows that even in the most ordinary circumstances, heroism can be accomplished. Though he was badly bruised, exhausted, and hungry, he prefers to endure pain and suffering during this battle with the giant marlin. At last, he kills the marlin but loses it to the

\begin{tabular}{lll|l}
$\mathbf{K}$ & $\mathbf{C}$ & AL-KINDI CENTER \\
$\mathbf{R}$ & $\mathbf{D}$ & FOR RESEARCH AN
\end{tabular} $\mathbf{R}$ D FEVELOPMENT Your gateway to world-class research

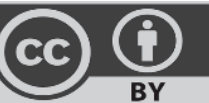

Published by Al-Kindi Center for Research and Development, London, United Kingdom. Copyright (c) the author(s). This open access article is distributed under a Creative Commons Attribution (CC-BY) 4.0 license 
predator sharks, though he takes pride in his defeat. As Santiago expresses that "a man can be destroyed but not defeated". Thus, this study will focus on analysing Santiago's motivation in catching the fish and his three-day battle with the marlin on the sea.

All in all, The Old Man and the Sea is not just a story of an old man and a big fish; rather it is a story of man versus nature conflict in the face of adversity. This article explores how Santiago, became a conventional hero in his epic battle against a big marlin to regain his lost reputation and dignity.

\section{Literature Review}

Ernest Hemingway published 'The Old Man and the Sea' in 1952, which became his last major work. In the novel, Santiago suffers from bad luck in his old age despite being a great fisher in his youth. According to Chiba (2019), it is easy to see the parallels between the old man in the novel and Hemingway. Hemingway had been trying to reclaim the literary success of his older books, such as "The Sun Also Rises" and "For Whom the Bell Tolls." In the story, Santiago could have success in the easier, nearer patches of water. Instead, he hunts for a bigger fish far out in the sea. Similarly, Hemingway too searches for a big success with his most ambitious writing project.

According to Schatz (2020), It is a simple story with a deeper message and a significance that surpasses time and place. It expresses the universal truths of a man's existence in this world, where courage, respect, honour, tenacity, pride, dreams, and visions incite man's quest to prosper amidst adversity. It is a tale of the indomitable spirit of man; the old man symbolizes an optimistic attitude toward life, and fights with the giant marlin, and offers life lessons to all. (Bryan Schatz,2020)

Santiago appears to be the spirit of struggle and hope in the dying circumstances when defeat is inevitable for the old man. The way he hooks the big marlin after 84 days seems no less than a miracle because no other fisherman would even think of staying against such a big fish, even in less deep waters than those where Santiago fought for his supremacy over the mighty nature. According to Shahwan (2019), it is this realization of identity that arouses the element of sub-consciousness that helps to prove the existence of inner being and reflect the individual recognition build on self-esteem and dignity that gives strength and power to fight back even in adverse situations.

Santiago is a man with great pride and courage. He proves this point through his statement, "But man is not made for defeat. A man can be destroyed but not defeated"... (80). His belief shows him a man of strong determination. His resolution can be seen in his long struggle with the marlin. He has unlimited willpower and self-confidence that enables him to win victory over his adversary. The old man exhibits patience and courage. He is determined to "stay with you until I am dead".(38). He tells the fish " I will kill you before this day ends". (40). He demonstrates himself as an expert and a skilful fisherman who knows the sea and its creature very well. Santiago judges not only the behaviour of the marlin but of the sharks as well. He believes in techniques and skill. He says, "It is better to be lucky. But I would rather be exact".(22).

Santiago is of optimistic temperament and has tremendous faith in success and confidence in the coming time. He is the man of wits and common sense. His prudence is his "trick". In the novella, Santiago says, "But I know many tricks and I have a resolution." (p.14). Santiago is proud of his skills and his accomplishments.

Santiago was known as an experienced fisherman and a champion angler throughout his youth not only for his strength but also known for the fishing skills. During his old age, he is at odds with his trends prevalent and due to his constant failure, he was termed "salao" by the fishing community. As Aslam and Khattak states (2014), Santiago cannot come to terms with the fact that he is not as agile and strong as the young anglers even though he has the skills, and he pushes himself too far in proving his worth and thus his character becomes one-sided. Santiago constantly reminds himself as a champion to be in the limelight; as such he shows confidence and pays more attention to his image and how he is perceived by others.

It seems Santiago takes pride to prove himself. According to Aslam and Khattak (2014), Pride, the virtue of the unconscious man is at the heart of Santiago's endeavours. He who has been a champion and has deep scars on his hands are reminiscence of his glorious catch and handling of big fish; can hardly take the scorn of younger anglers as they laugh at him thinking he is incapable of fishing anymore. Thus, he says after catching the fish, "how do you feel fish"... I feel good and my left hand is better, and I have food for a night and a day". (The Old Man and the Sea, 58). Thus, it proves the fact that he is not going to give in on this fish whatever may come. His reputation and his honour are at stake and Santiago is determined to prove his worth as a skilled and experienced fisherman.

As Cunningham (2016) states, the villagers view him as salao, (the worst form of unlucky), his old body racked and afflicted by years of pain and suffering except for his blue eyes that looked "cheerful and undefeated". Santiago begins his journey in the vast blue ocean one more time on the 85th day since his last catch and rows his boat far away into the deep sea, towards "the schools of Bonita and albacore" where he might do better: "My big fish must be somewhere" to prove his worth as a skilled and experienced fisherman. 


\section{Methodology}

The method used in this research is a descriptive objective approach that requires focusing on the intrinsic elements of the novel by analysing and explaining them in detail. Data obtained for the research is from two sources, a primary source is the text of the novel and the secondary source are the other sources such as, the internet, library research and is based on the findings of the related studies from various scholars.

\section{Findings}

The story is inspired by a real-life incident based on the life of an old Cuban fisherman. In his essay on deep-sea fishing published in 1936, Hemingway has given an account of an old fisherman who had caught a huge marlin which was approximately 800 pounds. The old man tied the fish to his boat and sailed homeward, but on the way, the sharks attached the dead marlin. He was rescued by some fishermen in a state of delirium. When Hemingway met him, he promised to write a book based on his experiences. A novel which he wrote later, The Old Man and the Sea. This novel skillfully blends facts and fiction to create one of the most poignant tales of all time. Santiago had to catch a big fish, and his quest to catch a fish is similar and symbolic of the author's quest to write a great novel.

The character of Santiago is based on the Cuban fisherman. Santiago is determined to prove himself again. According to Hemingway- "[T]he thousand times [Santiago] had proved it means nothing. Now he was proving it again. Each time was a new time and he never thought about the past when he was doing it" (Old Man and the Sea,49). The author uses flashback technique to emphasize the character of Santiago. He draws inspiration to face challenges at the sea, when he is reminded how he won the title of Champion after he defeated the negro in a hand game, he admires Joe DiMaggio for his endurance, and he reminisces about loins which represent strength, virility, and power. His past experiences help him to struggle and survive at sea and eventually restore his reputation. For example, during his voyage on the sea, he distracted himself by talking to the birds and followed them which led him to find the massive fish.

When Santiago caught the fish, he deterred the fish from escaping by loosening the fishing line so that the fish will not break his pole. Instead, the fish dragged his boat into the sea for three days. A bond of kinship and honor develops between the old man and the fish. Gradually, the huge fish and a noble adversary grew tired and exhausted, and eventually Santiago killed it. Although Santiago was successful in catching the fish, he was far away in the deep sea. His ordeal at sea was not over. He has to struggle hard and drag the huge marlin behind the boat, and the fear of bleeding fish that might attract the sharks haunted him. Thus, Santiago's immense willpower and his natural instincts help him in his affliction at the sea.

When the sharks attacked the dead marlin, Santiago fought fearlessly but his efforts proved futile and in vain. The sharks devoured the flesh of the marlin, and Santiago was left only with the skeleton. Though fatigued and tired, Santiago heads back to the beach. He has nothing to show for his anguish and suffering except the ruined remains of a huge marlin. Nevertheless, the encounter at sea has transformed him from a state of despair to hope and even changed the perception of others towards him. When the fishermen saw the huge skeleton, they were amazed and felt respect for Santiago.

During his ordeal on the sea and to keep up his spirits, Santiago reminded himself of his past feats as a Champion in a hand game where he defeated the negro with his willpower and determination. He drew inspiration from a famous baseball player, Joe DiMaggio known for his perseverance and endurance, to face challenges at sea and to uphold his need of pride and honour. Thus, he exhibits qualities of heroism by proving himself as a worthy fisherman even though he was frail, weak, and fatigued.

This story also demonstrates how Santiago proves himself throughout the novella that physical impediments are inconsequential as compared to one's self-respect and tenacity when it eventually comes to the question of survival. Although the fellow fishermen do not trust him, and the boy (Manolin) was denied by his parents to go with him, he still goes fishing by himself. Santiago shows an unusual amount of emotional strength and confidence. Even though he was physically challenged because of his old age, he still prefers to go fishing alone. He upholds his ethics and his principles despite risky adventures and endures through the challenges on the sea when exposed to the vast nature. As a result, his internal strength emerged stronger.

Just like Santiago, we all in this life are fighting in many different ways to survive as well as all the other creatures on this earth too. We can see how Santiago has a firm determination and intention to hook the fish and to show to others how he remains undefeated. It simply proved how strong he was, with a mindset of not quitting and not giving up, no matter how tough and challenging it would be. The novella shows Santiago's amazing and unbeatable willpower and mental strength despite his physical exhaustion due to old age. Santiago believed with positive attitude and hoped one can overcome all the hardships and challenges.

In the novel, when Santiago relates to his adversity, he seems to be a dignified man, he does not want to ask for charity to others despite his poor living condition. He states, "I think maybe I can too. But I try not to borrow. First you borrow. Then you beg." (10). At one point Santiago asserts, "My big fish must be somewhere." (24). In fact, he is confident that one day his great fish will come, 
and along with it, the luck will return to smile at him once more. This shows that Santiago is a positive person full of hope and faith. He believes in his work and discipline, performing what he was born for when he says, "You were born to be a fisherman as fish was born to be a fish." He is determined and passionate about fishing. He not only want to catch a big fish for money, but his goal is to prove his fishing skills and to reassert his identity as a great fisherman.

As Asalm and Khattak (2014), puts it, Santiago's philosophy of life values and ethics all depend on public opinion. His moral values are the same as the ones his society professes. His behavior does not show any contradiction in spite of the conflict going on in his mind regarding his misfortune, and yet he maintains his self-respect. For example, when Manolin brings him supper to eat with knives and forks and spoons wrapped in napkins Santiago expresses his gratitude for the Terrace owner by saying, "I must thank him" (10). Moreover, when Manolin says he has already done that the old man says, "I'll give him the belly meat of a big fish".(11). He then further asks Manolin if the Terrace owner had done this for them more than once. Hence, what he is to society and how society sees him is of constant significance to him. He avoids any such behavior or action in the community that can potentially impair his image.).

Though ravaged by life, Santiago maintains his dignity by sharing his experience and wisdom with the young boy, Manolin, who loved and admired Santiago. The boy showed devotion and respect for him and in the end, he stands up against his parents and returns to Santiago's boat as an apprentice to learn more about fishing. He symbolizes friendship, unconditional love, and loyalty in the novel. He believes in Santiago's ability and his fishing skills.

The novel is an allegory of human aspiration, struggle, and transcendence. At the end of the novel, Santiago evokes the image of Jesus Christ who endured pain and suffering and was characterized as a good human being, so is Santiago who is modest and humble. Once Manolin said that "He is the best fisherman", and Santiago replies "No, I know others better". (14). A long time ago, his vanity disappeared when he lost the marlin. The only thing that remains with him is his humility combined with enormous fatigue. The old fisherman is very kind and compassionate. He loves the sea animals such as dolphins, flying fishes, the sea turtles, "with their elegances and speed". (24). The marine mammals such as porpoises that give him joy declares, "They are our brothers like the flying fish".(p.35). He felt sorry for the great marlin that he had caught and added. "Never I had such a strong fish nor one who acted so strangely." (35). Santiago is a modest man who never shows off his fishing accomplishments. He remains true to himself. He does not blame the circumstances for his failures and continues his fishing expeditions confidently.

\section{Conclusion}

Consequently, through this short novel, Hemingway rejoices the daring spirit and the resolution of the old fisherman. Hemingway praises him for his life's struggles alone. He is fierce, brave, bold, and daring. He displays Hemingway's views of an indestructible human spirit at its best.

In the novel, we also find that the boy admires the fact that the old man teaches him about fishing. He respects him a lot, for he knows that the old man is wise and an experienced fisherman. At the end of the novella, the fishermen showed respect towards the old man as they measure the size of the fish. The owner of the cafe, Martin says, "What a fish it was, there has never been such a fish". (p.96) The fishermen appreciate the fact that the old man has caught the biggest fish that they have ever seen. It was eighteen feet long. The fellow fishermen resented Santiago at first, but toward the end they realized what the old man has gone through alone on the sea. Their views for him changed and they showed respect for him. The story has deep ideas about the hardships and the struggles in life and how to overcome them. The novella teaches us that being valued and respected by others enhances one's morale. According to Lakshmi (2019), the tearing down of the marlin by sharks was not a loss for the old man; rather, it led to his absolution. The fishermen who ridiculed Santiago in the past stood in awe when they saw the carcass of the great marlin. Thus, Santiago regained his lost reputation and dignity, even though he did not succeed, not in the way he had expected, but in a unique way, undefeated.

As Chiba states, (2019), that the ending of the story is not depressing or demoralizing. The story describes the triumph and despair of an old man. Santiago goes to bed, has some food when he wakes up, rested for few days, and then goes fishing again to repeat the whole process. Santiago has reaffirmed who he is in his old age; he has justified that he does not need to change. Resolute, unyielding, and determined, Santiago once again proved his worth and thereby able to restore his dignity, and honour and he re-establishes his reputation in the fishing community.

Hemingway's novella The Old Man and the Sea exhibits universal truth in depicting the ordeal of an old man battling against poverty, isolation, old age, loneliness to sustain his self-esteem. Santiago's epic struggle not only reclaims himself but encourages and enriches those around him.

In the end, the novel shows Santiago a changed man from his earlier despair from not catching a fish to the state of hope. Santiago's struggle displays the aptitude of the indomitable spirit of man that endures suffering and adversity in order to 
succeed. Santiago's adoration and knowledge of the sea, in its inscrutable ferocity and magnanimity, permits him to survive. Thus, Hemingway succeeds in portraying the character of Santiago, as a man who proves himself by overcoming the challenges of life and mother nature. And also, as a man who finally regains his lost reputation and honour.Further research can be conducted on this novel.I think this is a classic novel and contains deeper meaning of life. It can be explored further through themes, such as human endeavors in the face of extremity.

\section{References}

[1] Chiba, S. (2019). Book Review: 'The Old Man and The Sea' By Ernest Hemingway. Available from :https://www.oxfordstudent.com/2019/11/10/the-old-man-and-the-sea-by-ernest-hemingway/ [Accessed 18 January 2021].

[2] Cunningham, R (2016). Books to give you hope: The Old Man and the Sea by Ernest Hemingway. Available from: https://www.theguardian.com/books/booksblog/2016/aug/24/books-to-give-you-hope-the-old-man-and-the-sea-by-ernest-hemingway [Accessed 29 January 2021].

[3] Aslam H., \& Khattak (2014). Santiago: A Lop-Sided Character in The Old Man and the Sea. Available from: https://www.thefreelibrary.com/Santiago:+A+Lop-Sided+Character+in+The+Old+Man+and+the+Sea.-a0398959401 [Accessed 1 February 2021].

[4] Schatz, B (2020). Lessons in Manliness from The Old Man and the Sea. Available from : https://www.artofmanliness.com/articles/lessons-inmanliness-from-the-old-man-and-the-sea/ [Accessed 23 January 2021].

[5] Topham, J (2020). The Old Man and the Sea' Review. Available from: https://www.thoughtco.com/old-man-and-the-sea-review-740952

[6] Shahwan, S. J. (2019). A Lacanian Study of Hemingway's The Old Man and the Sea. Mediterranean Journal of Social Sciences, $10(1), 87$. [Accessed 26 January 2021].

[7] Lakshmi K. R, (2019). Struggle Between Humanity and Nature in Ernest Hemingway's THE OLD MAN AND THE SEA Available from: https://literaryendeavour.org/special-issues/SE-Jul-2018.pdf\#page=204 [Accessed 20 January 2021].

[8] Ernest, H. (2004). The Old Man and the Sea. , Arrow books. 